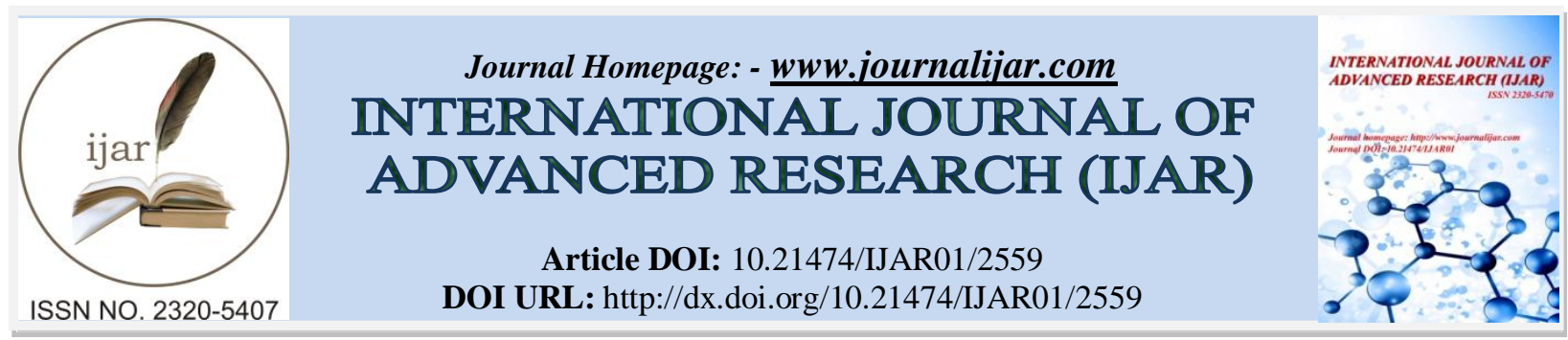

RESEARCH ARTICLE

\title{
REMOTE SENSING AND GIS IN SUPPORT OF THE CHARACTERIZATION OF THE CLIMATE IN MAURITANIA: CASE OF THE DIAWLING NATIONAL PARK (PND) AND ITS PERIPHERAL ZONE.
}

Ould Abidine Mohamed Mahmoud ${ }^{1}$, Ahmed El Aboudi ${ }^{1}$, Inejih Cheikh Abdellahi ${ }^{2}$ and Ahmedou Soule ${ }^{3}$.

1. Laboratoire de botanique, Mycologie et Environnement, Faculte des Sciences, Universite Mohamed V, RabatMaroc , 4 avenue ibn battouta BP 1014

2. Ddecomar, Reseau Developpement Durable et Ecosystemes Marins.

3. Ecole Normale Superieure de Nouakchott_Mauritanie BP 990.

\section{Manuscript Info}

\section{Manuscript History}

Received: 27 October 2016

Final Accepted: 25 November 2016

Published: December 2016

\section{Key words:-}

NDVI, TRMM, MODIS, PND, drought, climate, Mauritania

\section{Abstract}

The climate is the fundamental factor that determines the Sahelian natural environments. Mauritania is one of the Sahelian countries most affected by droughts that have followed since 1970. This succession of drought has weakened vegetation and caused soil depletion. This study characterizes the climate trends of Diawling National Park (PND) and its peripheral area over the period 2000-2013. It seeks to highlight the importance of space data for climate characterization in the Sahel region, using maximum and minimum temperatures derived from MODIS imagery (with a resolution of $0.05^{\circ}$ or $5 \mathrm{~km}$ ) and rainfall data derived from TRMM (with a spatial resolution of $0.25^{\circ}$ or $25 \mathrm{~km}$ ). These two parameters were compared with the vegetation index (NDVI, derived from MODIS images with a temporal resolution of 16 days and a spatial resolution of $250 \mathrm{~m}$ ). The results from the spatial data were validated referring to Rosso meteorological station.

Copy Right, IJAR, 2016,. All rights reserved.

\section{Introduction:-}

In Mauritania as in all Sahelian countries, the drought observed over more than thirty years has often had serious consequences on all terrestrial and aquatic ecosystems (Servat et al., 1998, Nicholson, 1978 and 1998). This drought is explained by a large rainfall deficit observed since the late 1970s (Ozer, 2000; Ozer et al., 2014); A deficit that has profoundly affected all agricultural, steppe, and other ecosystems.

In addition, climate monitoring through direct measurements of the parameters to characterize states and trends has not always been possible and has been carried out on a continuous basis. Estimates from indirect sources are often used.

In this perspective, our study aims to study the temporal and spatial evolution of some climatic parameters, in particular precipitation and to see the impact of this water deficit on the vegetation of the Diawling National Park (PND) and its peripheral zone over the period of 2000-2013. To do this, we tested the contribution of spatial data as an indirect source with the CHIRPS and TRMM data for precipitation, MODIS data for surface temperatures and NDVI vegetation index. The use of spatial data is justified by the fact that the meteorological stations in Mauritania as in most African countries are lacking and when these data exist, they are often fragmentary. Also, from a practical

Corresponding Author:- Ould Abidine Mohamed Mahmoud. 
standpoint, the characterization of the climate from spatial data has never been carried out for the Diawling National Park (PND) and rarely in Mauritania.

\section{Overview of the Study Area:-}

The Diawling National Park (PND) belongs to the Wilaya of Trarza. It is created by Decree No. 91-005 of 14 January 1991. In 1994, this park is classified as a wetland of international importance (Ramsar site). This wetland covers an area of 16,000 ha. Its peripheral zone covers an area of 52,000 ha. The PND lies between $16^{\circ} 05$ 'and $16^{\circ}$ $35^{\prime}$ north latitude and $16^{\circ} 20$ 'and $16^{\circ} 30^{\prime}$ ' west longitude (Fig.1).

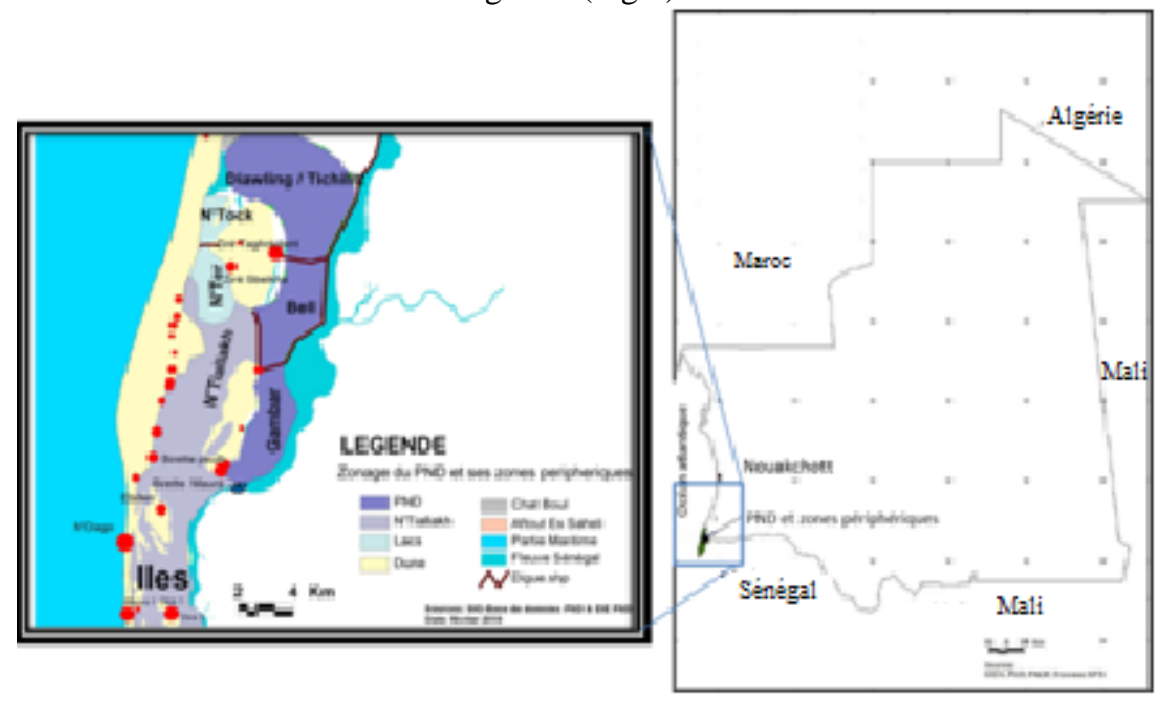

Figure 1:- Location of Diawling National Park and its peripheral zone.

The PND consists of the Diawling basin (10 000 ha of which 8000 in the park), fed by the Cheyal, the Bell basin (4 $000 \mathrm{ha}$ ) fed by the Lemer structure and evacuated by the Berbar work to the north and by works Bell1 and Bell2 and the Gambar basin which is part of the Diama reservoir (Hamerlynck O. 1997, Duvail S. 2001).

The whole is inscribed between the coastal dune to the Northwest, the dunes of Birette and Zire and the dyke connecting them, in the West and the banks of the Senegal River in the East. Indeed, it is under the effects of fresh water coming from the Senegal River and salt water of marine origin linked to the tides.

The PND has a very diverse range of terrestrial and aquatic ecosystems, organized around floodplains fed by rainwater and artificial flooding (through hydraulic works of the river), continental and coastal dunes, Islands sheltering mangroves to Avicennia germians and Rhizophora racemosa. This environment is a spawning area for lots of freshwater and estuarine fish and shrimp. It is an important nesting place for birds such as, among others, flamingos, cormorants, herons, egrets, spoonbills. The flora consists mainly of Sporobolus robustus, Acacia nilotica, and Nymphea lotus, which serve as a basis for the economic activities of the populations

\section{Data used:-}

To achieve these objectives we have downloaded the TRMM precipitation images with a resolution (in degrees) of $0.25^{\circ} \times 0.25^{\circ}$, images of maximum and minimum temperatures MODIS with a resolution of $0.5^{\circ} \times 0,5^{\circ}$ and the MODIS Vegetation Index (NDVI) with a resolution of 250m, for a period of 13 years from 2000 to 2013.

Climate data are available on NASA and JAXA sites in several forms (daily or monthly data). In this study we used the monthly data of TRMM 3B43 were judged of good quality by Collischonn et al. 2006 and Collischonn et al. 2007. For each year twelve images have been downloaded separately, each image corresponds to a month, the same for the temperatures. In contrast, for the Vegetation Index, two images per month were downloaded, a total of 24 images per year.

All images were georeferenced, for precipitation, data are recorded in $\mathrm{mm} /$ hour and temperatures in degrees Kelvin, using an ENVI program, precipitation is converted to $\mathrm{mm} / \mathrm{month}$ and temperatures in degrees Celsius . 


\section{Results and Discussion:-}

The annual precipitation study clearly showed a variation in annual totals during the study period with annual averages ranging between 175.82 and $478.53 \mathrm{~mm}$ (Fig.3). We can see from this figure that the average annual precipitation recorded during the period 2000-2013 in the Diawling National Park (PND) and its peripheral zone is of the order of $308.03 \mathrm{~mm}$. The years 2004, 2007, 2008 and 2011 showed a significant water deficit with rainfall averages below $308.03 \mathrm{~mm}$. On the other hand, 2009, 2010 and 2013 were the most watered of this period with annual averages above $308.03 \mathrm{~mm}$; the year 2010 is the rainiest with an average of $478.53 \mathrm{~mm}$. The general trend of the curve obtained shows that the climate of the Darling National Park (PND) is of the Sahelian type and is characterized by a large variation in precipitation from one year to the next. Regarding the temperature variations of the study area during the period 2000-2013 (Fig. 4), this figure shows that the annual mean temperature of the Diawling National Park (PND) is almost constant and oscillates between $24^{\circ} \mathrm{C}$ and $25^{\circ} \mathrm{C}$ during the period 20002013. However, during this period, there was a significant variation in monthly averages. The maximum temperatures (M) regularly exceed $34^{\circ} \mathrm{C}$. These values are recorded during the hottest months (April and May) while the minimum temperatures recorded range from 15.5 in January to $23.4^{\circ} \mathrm{C}$ in September, the months of December and January being the coolest months. The Dawling National Park Ombrothermal Diagram and its peripheral zone (Figure 5) based on the TRMM and MODIS surface temperature data showed/demonstrated that the climate of the study area can be subdivided into three seasons: A rainy and warm season "or wintering" corresponding to the months of August-September; A dry - cold season from October to January; A warm dry season from Mars to July.

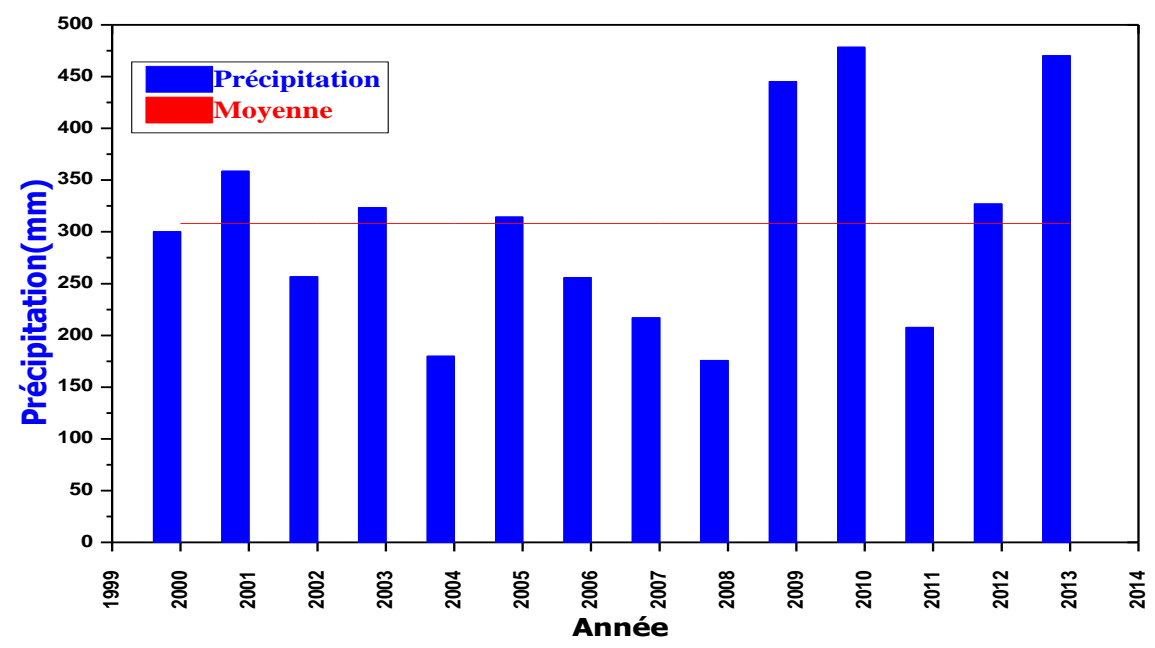

Figure 2:- Annual rainfall trends over the period 2000 to 2013 

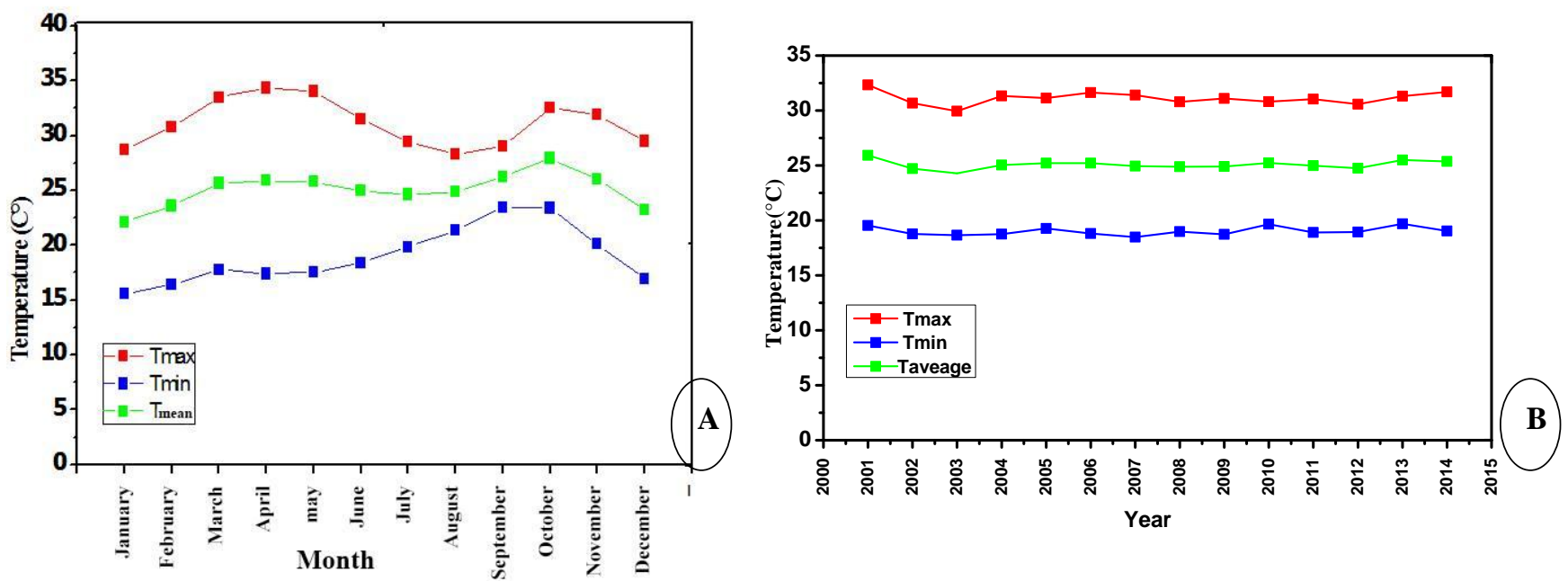

Figure 3:- Evolution of Monthly Temperatures (A) and Evolution of Annual Temperatures (B)

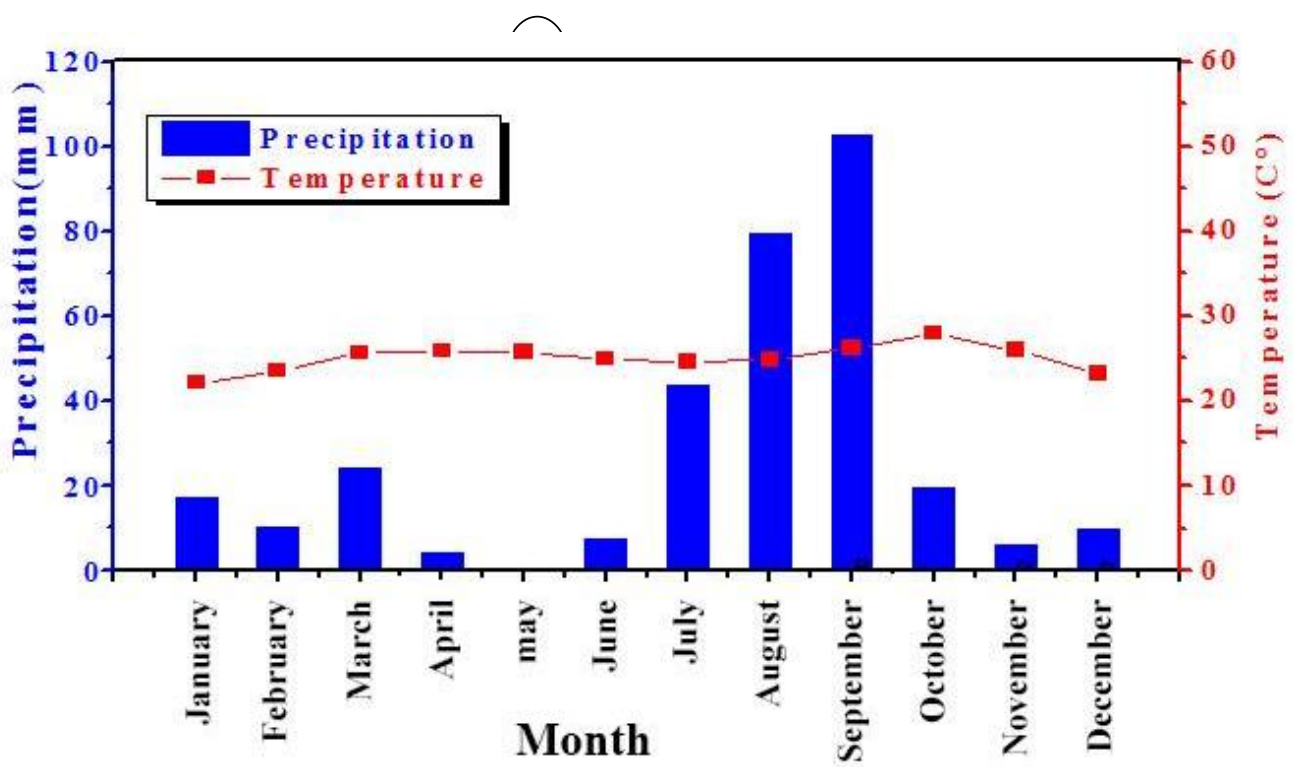

Figure 4:- Ombrothermal Diagram of the Diawling National Park and its Peripheral Zone

The standardized vegetation index (NDVI) is widely used throughout the world as a measure of vegetation vitality, with high NDVI values indicating vigorous vegetation.

The relationship between vegetation indices and precipitation has been used by several authors to monitor vegetation cover (Evans and Geerken, 2004). NDVI is a good indicator of changes in the state of vegetation, therefore it has been used to track drought in the study area.

The TRMM data and the annual average of the vegetation index calculated from the images downloaded from the MODIS site are crossed in order to detect the evolution of the state of the vegetation according to the precipitation of the Diawling National Park and its (FIG. 6). The figure above shows that the NDVI index evolves in the same direction as precipitation except for the years 2006 and 2007 where the vegetation index showed an increase despite the decrease in precipitation, probably due to the effects of variations. The duration and quantities of water from artificial floods. NDVI values range from 0.21 to 0.27 . It is also noted that average NDVIs never exceed 0.27, reflecting the low density of vegetation on the Park. 
The TRMM 3B42 data are used to characterize the spatiotemporal variability of the Rosso station (WMO 61489) which has existed since 2 January 1957, a first stage of validation of the data is necessary to ensure their quality. They show (demonstrate indicate) that the relationship is strongly positive except for certain years (2001, 2007 and 2013). Regarding the relationship between mean temperatures, it is shown that there is no significant correlation between LST Modis (between $24^{\circ} \mathrm{C}$ and $25^{\circ} \mathrm{C}$ ) and Tsol (between $29^{\circ} \mathrm{C}$ and $30^{\circ} \mathrm{C}$ ) Of meteorological station of Rosso (fig7). This is partly due to the proximity of the sea to the coastline; the mean temperature varies by $25^{\circ} \mathrm{C}$, whereas the temperature of the indoor air is $30^{\circ} \mathrm{C}$ (Hamerlynch, 1997).

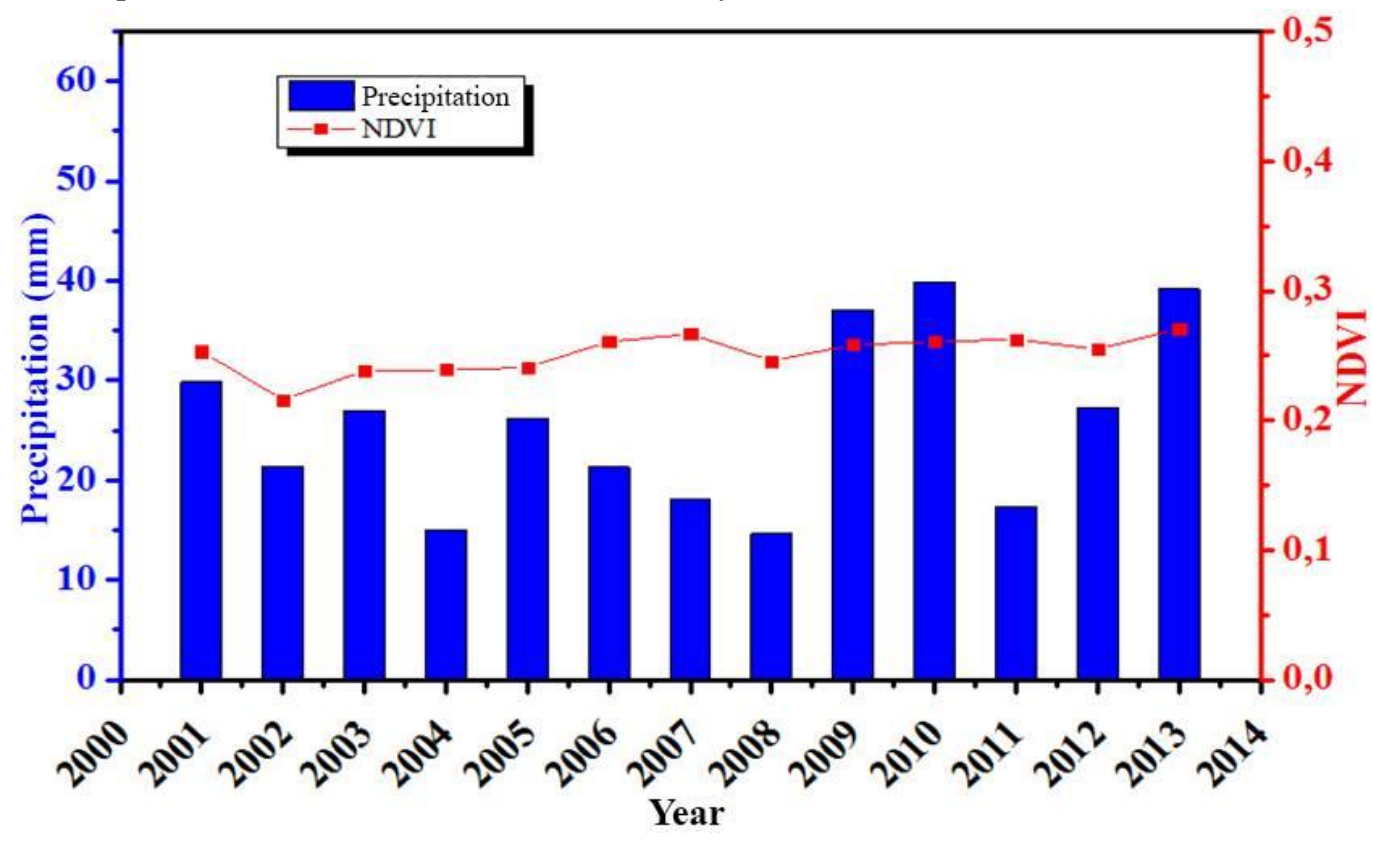

Figure 5:- Relation entre la moyenne annuelle des précipitations et la moyenne annuelle de NDVI du Parc National du Diawling et sa zone périphérique
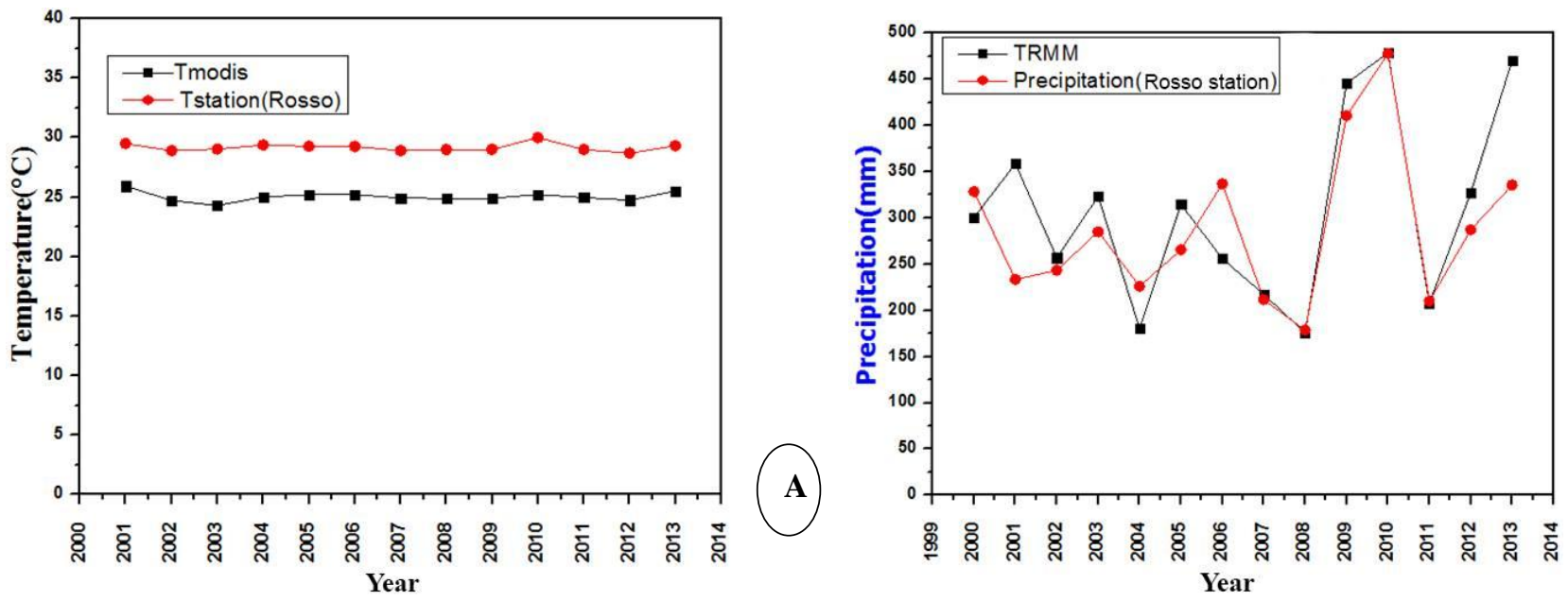

Figure 6:- Relationships between satellite data and Rosso meteorological stations: annual temperatures (A) and annual precipitation (B)

\section{Conclusion:-}

This work was carried out on the Darling National Park (PND) and its peripheral zone, which is rightly considered as a fragile ecosystem exposed to the phenomenon of desertification (Ould Mohamedou Abdallahi., 1998). Dawling National Park has seen the emergence of an invasive aquatic species Typha australis, which has inflicted invaluable damage on the wetlands of the Senegal River Valley, which has directly threatened human, animal and biodiversity health in The Diawling National Park (Ould Abidine Mohamed Mahmoud et al, 2016). 
The use of remote sensing and GIS provides accurate information about precipitation and temperature and vegetation on the study area.

The results also have helped build an understanding of the climate and vegetation of Dawling National Park and its surrounding area. The evolution of the annual average of the vegetation index (NDVI) has continued the precipitation except for certain years (2006 and 2007).

\section{References:-}

1. Collischonn B., Allasia D., Collischonn W. et Tucci C. E. M., 2006. Estimativas de precipitação por sensoriamento remoto passivo: desempenho do satélite TRMM na bacia do alto Paraguai até Descalvados.Anais $1^{\circ}$ simposio de geotecnologias no Pantanal, Campo Grande (Brésil), 11-15 novembre 2006, 47-56.

2. Collischonn B., Allasia D., Collsischonn W. et Tucci C. E. M, 2007. Desempenho do satelite TRMM na estimativa de precipitação sobre a bacia do Paraguai superior. Revista Brasileira de Cartografia, 59, 93-99.

3. Diawara Y., (1997). Rapport de consultation : actualisation des données de la végétation et validation des relevés cartographiques du Parc National du Diawling, MDRE, UICN, p 23.

4. Duvail S., 2001. Scénarios hydrologiques et modèle de développement en aval d'un grand barrage. Les usages de l'eau et le partage des ressources dans le delta mauritanien du fleuve Sénégal, Thèse de doctorat de géographie, Université Louis Pasteur Strasbourg I, 313 p.

5. Evans J., Geerken R. 2004. Discrimination between climate and human-induced dryland degradation. Journal of Arid Environment, 57, 535-554.

6. Hamerlynck O. \& CAZOTTES F. 1996. Le parc national du dawling (Mauritanie) : infrastructures hydrauliques pour la restauration d'une plaine d'inondation et la création d'un estuaire artificiel 31 pages.

7. Hamerlynck O. 1997. The Diawling National Parc, Mauritania: joint management for the rehabilitation of a degraded coastal wetland. PND, Mauritanie : $18 \mathrm{pp}$.

8. Hamerlynck,O. \& ould Samba E. 1996. Le Parc National du Diawling: restauration d'une plaine d'inondation et création d'un estuaire artificiel, Bulletin de liaison et d'information du groupe de travail oiseaux. migrateurs du paléarctique occidental 14: 31-40..

9. Nicholson S.E., 1978. Climatic variations in the Sahel and other African regions during the past five centuries. Journal of Arid Environments, 1, pp. 3-24.

10. Nicholson S.E., 1998. Interannual and interdecadal variability of rainfall over the African continent duringthe last two centuries. Water resources variability in Africa during the XX century (Servat, Hugues, Fritsch et Hulmeeds), IAHS Publication n ${ }^{\circ} 252$, pp. 107-116.

11. OULD ABIDINE Mohamed Mahmoud., Ahmed EL ABOUDI., INEJIH Cheikh Abdellahi ., Ahmedou SOULE., 2016. Télédétection et SIG en appui à la caractérisation du climat en Mauritanie: cas du Parc national du Diawling (PND) et sa zone périphérique. European Journal of Scientific Research Vol. 142 pp.387-395.

12. Ouldi Mohamedou Abdallahi.,1998. Contribution a l'etude du Parc National du Diawling, eaux, sols, vegetation. Contribution to study of the Diawling National Park water-soils-vegetation, $155 \mathrm{p}$.

13. Ozer P. 2000. Les lithométéores en région sahélienne : un indicateur climatique de la désertification. - GEOECO-TROP, 24, 1-317.

14. Ozer P., Hountondji Y. C. Gassani J. Djaby B., DE Longueville F., 2014. Evolution récente des extrêmes pluviométriques en Mauritanie (1933-2010). Actes du XXVII Colloque de l'Association Internationale de Climatologie, 2-5 juillet 2014 - Dijon (France), 394-400.

15. Servat E., Paturel J.E., Kouame B., Travaglio M., Ouedraogo M., Boyer J.F., Lubes-Niel H., Fristch J.M., Masson J.M., Marieu B., 1998. Identification, caractérisation et conséquences d'une variabilité hydrologique en Afrique de l'Ouest et Centrale. Water Ressources Variability in Africaduring the XXth Century, 323-337 